\title{
Revision of the "Archidiskodon meridionalis ürömensis" Vörös, 1979 in the context of the mammoth evolution in Eurasia
}

\author{
Attila Virág \\ Department of Paleontology, Eötvös Loránd University, \\ Budapest
}

\begin{abstract}
A single tooth from the locality of Üröm-hegy (Hungary) was designated as the holotype specimen of "Archidiskodon meridionalis ürömensis" by Vörös (1979). The observed morphology of the tooth, with a minimum of 15 molar plates (most likely 17) led to the conclusion that this specimen belongs to Mammuthus trogontherii rather than a subspecies of $M$. meridionalis. On the basis of rodent biostratigraphy a date in the region of MIS 19-17 seems likely (i.e. c. $0.8 \mathrm{Ma}-$ c. $0.7 \mathrm{Ma}$ ). Taking into account the meridionalis-like enamel thickness ( 3.1 to $3.4 \mathrm{~mm}$, mean $3.2 \mathrm{~mm}$ ) as well as the intermediate or slightly advanced relative crown height (1.65) and lamellar frequency (6), the specimen shows mosaic morphology, which fits well in the framework of the contemporaneous European mammoth-bearing localities (e.g. Voigtstedt). Taking all the evidence together it seems that this molar is not only a misinterpreted specimen, but a representative of a very important period of mammoth evolution in Eurasia, when $M$. meridionalis and $M$. trogontherii occurred together in Europe and when the genetic mixing between the adjacent populations resulted in a hybrid zone, which was responsible for mosaic or intermediate individuals, such as the holotype of "Archidiskodon meridionalis ürömensis".
\end{abstract}

Key words: Elephantidae, Archidiskodon, Mammuthus, uromensis, Early-Middle Pleistocene transition

\section{Introduction}

The European mammoths have conventionally been divided into four chronospecies: the Late Pliocene M. rumanus, the Early Pleistocene M. meridionalis (recorded about 2.6 to $0.7 \mathrm{Ma}$ ), the latest Early Pleistocene and Middle Pleistocene $M$. trogontherii (recorded about 1.0 to $0.2 \mathrm{Ma}$ ) and the latest Middle Pleistocene and Late Pleistocene M. primigenius (Lister et al. 2005).

Address: $\quad$ A. Virág: H-1117 Budapest, Pázmány Péter sétány 1/c, Hungary e-mail: myodes.glareolus@gmail.com

Received: June 21, 2010; accepted: November 3, 2010 
In the interval 1.0-0.7 Ma, a series of samples in Europe illustrates a complex and fascinating transitional period between $M$. meridionalis and $M$. trogontherii (Lister et al. 2005). A proliferation of subspecies (e.g. Archidiskodon meridionalis cromerensis Depéret and Mayet, 1923 and Mammuthus meridionalis depereti Coppens and Beden, 1980 from Western Europe, A. m. voigtstedtensis Dietrich, 1965 from Central Europe as well as A. m. tamanensis Dubrovo 1964 from Eastern Europe) were erected on the basis of the fossils from this period. The situation is further complicated by the fact that some of the material on which the subspecies were based is refereble to $M$. trogontherii (see Lister et al. 2005, for a detailed discussion).

In the light of recent studies it appears that "Archidiskodon meridionalis ürömensis" Vörös 1979 (from the Carpathian Basin) is also a representative of this important period of mammoth evolution, when $M$. meridionalis and $M$. trogontherii occurred together in Europe with some specimens which show "mosaic" tooth and post-cranial morphology.

\section{Measurements}

The method for measuring morphological and biometrical parameters of elephantid molars is based on the methods of Maglio (1973) and Beden (1979). These methods were later adapted and modified by other authors (e.g. van den Bergh 1999; van Essen 2003). The measurements were performed with digital calipers with a precision of 0.3 millimeters. The biometrical parameters used in this paper (Fig. 1.) are the following:

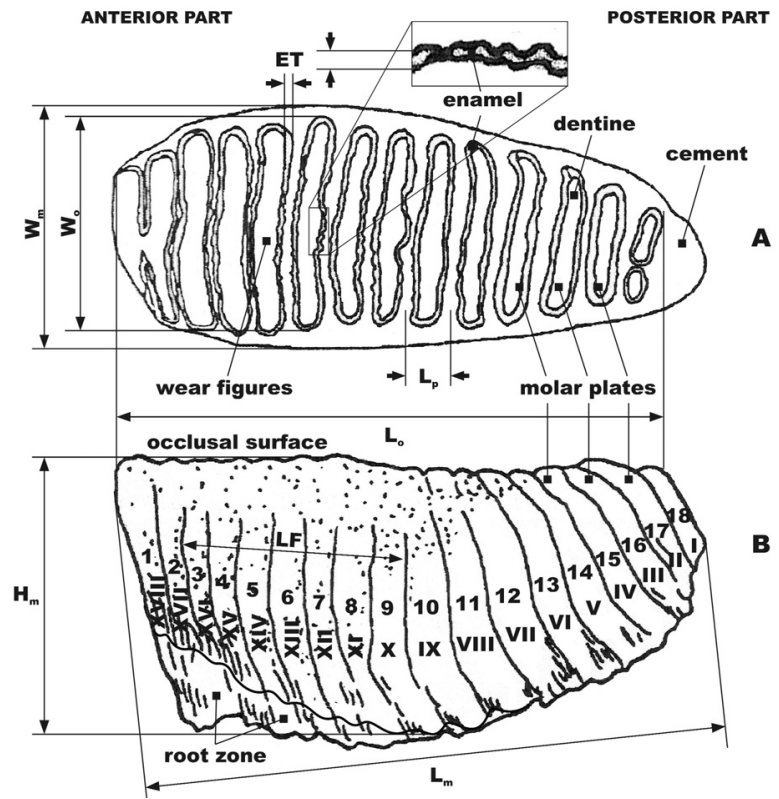

Fig. 1

Terminology and measurements of mammoth molars (further explanation in the text) (modified from Foronova 2007). Legend: A = $\mathrm{m} 3$ in occlusal view, $B=\mathrm{m} 3$ in buccal view, $\mathrm{L}_{\mathrm{m}}=$ maximum length of the molar, $L_{\mathrm{o}}$ : maximum length of the occlusal surface, $\mathrm{L}_{\mathrm{p}}$ : average length of a single plate, $W_{m}$ : maximum width of the molar, $\mathrm{W}_{\mathrm{o}}$ : maximum width of the occlusal surface, $\mathrm{H}_{\mathrm{m}}$ : maximum height of

B the molar, LF: laminar frequency on $100 \mathrm{~mm}$, ET: enamel thickness. Molar plates are marked with Arabic numerals when counting from anterior in posterior direction and with Roman numerals when counting from posterior in anterior direction, as indicated in fig. B 
P: Number of plates (or lamellae) present in one molar. A dash (-) in front or behind the plate number indicates incompleteness of the molar. If a plate is incompletely preserved, $1 / 2$ or $1 / 4$ is put in front or behind the plate number. The fractions do not designate the posterior and anterior talons and platelets. The latter are not counted; they are indicated with " $x "$. The estimated number of plates missing is given between brackets if possible. The estimation can be based on the extent of loss of the first root. Thus $(x ? 2)^{1} / 27 x$ means that, of a molar fragment with 8 plates (the first of which is broken) and a posterior talon or platelet remaining, two plates and possibly an anterior talon are lacking at the front.

$\mathrm{P}_{\mathrm{u}}$ : Number of plates in use.

$\mathrm{L}_{\mathrm{m}}^{\mathrm{u}}$ : Maximum length of the molar, measured along the longitudinal axis, perpendicular to the planes of the intermediate plates.

$\mathrm{L}_{\mathrm{o}}$ : Maximum length of the occlusal surface, measured along the longitudinal axis.

$\mathrm{L}_{\mathrm{p}}$ : Average length of a single plate (including dentine, enamel and $1 / 2$ of cement interplate space on both sides of a plate), measured along the longitudinal axis of the molar.

$\mathrm{W}_{\mathrm{m}}$ : Maximum width of the molar, measured on the widest plate of the molar, parallel to the anterior and posterior surfaces of the plate. To avoid bias it is better to measure $\mathrm{W}_{\mathrm{m}}$ without the cover cement.

$\mathrm{W}_{\mathrm{o}}$ : Maximum width of the occlusal surface, measured on the widest enamel figure, parallel to the anterior and posterior surfaces of the plate.

$\mathrm{H}_{\mathrm{m}}$ : Maximum height of the molar, measured vertically on the lateral side of the highest plate, between the crown base (the lateral-basal enamel extreme of the plate) and the apices of the digitations. Values taken on slightly worn plates are indicated with "+" behind the measured value.

$\mathrm{H}_{\mathrm{m}} / \mathrm{W}_{\mathrm{m}}$ : Hypsodonty index (or relative crown height) represents the ratio of the maximal height and the maximal width

LF: Laminar frequency represents the number of plates that occur within $10 \mathrm{~cm}$ along the longitudinal plane of the molar. The LF values were obtained by measuring the distances between at least two valley separating three or more plates, both on the lingual and buccal side of the molar. If these distances (expressed in millimeters) are indicated with $d_{1}$ (lingually) and $d_{b}$ (buccally), and the number of plates between the two measuring points with $n$, than the LF was calculated using the formula: $L F=\left(100 n / d_{1}+100 n / d_{b}\right) / 2$.

ET: Enamel thickness is measured perpendicular to the anterior or posterior enamel surface of molar plates. Within one molar the enamel thickness is not constant and maximum and minimum value are given if possible. As the enamel usually decreases in thickness towards the base of the plates, only those measurements are included, which could be taken in plates that are worn less than two-thirds. In unworn but broken molar fragments the ET could be obtained on vertical broken enamel surfaces. 
Measurements on incomplete molars or bones are followed by "+", indicating that the value of the original element was larger than the recorded value. If a measurement represents an estimated value, that value is succeeded by "e". The $\mathrm{H}_{\mathrm{m}}$ and $\mathrm{W}_{\mathrm{m}}$ values taken on molar plates completely covered with cement are followed by "c". Specific plates of a molar are indicated with an Arabic numeral when counted from anterior in posterior direction, and with a Roman numeral when counted from posterior in anterior direction (in molars that are incomplete in front).

\section{Systematic part}

It is important to mention the main features of the considered taxa $(M$. meridionalis and $M$. trogontherii) prior to the revision of the "Archidiskodon meridionalis ürömensis" Vörös 1979. Fossils are described as being the "typical" form of each of these species when they are statistically indistinguishable from the sample of the type locality.

Class Mammalia Linnaeus, 1758

Order Proboscidea Illiger, 1811

Family Elephantidae Gray, 1821

Subfamily Elephantinae Gray, 1821

Genus Mammuthus Brookes, 1828

\section{Mammuthus meridionalis (Nesti) 1825}

Mammuthus meridionalis was defined on the basis of material from the Upper Valdarno, Italy. By 0.6 Ma, at Süssenborn (Germany) and elsewhere, this species has been completely replaced by $M$. trogontherii (Lister et al. 2005).

The description given below is mostly based on the work of Maglio (1973) and concerns the third upper molars (M3).

Plate formula: dp2: 3-4, Dp2: 3-4, dp3: 5-6, Dp3: 5-6, dp4: 7-9, Dp4: 7-8, m1: 8-10, M1: 7-10, m2: 8-10, M2: 8-11, m3: 10-14, M3: 11-14.

The plate number $(\mathrm{P})$ on the third upper molar (M3) is between 11 and 14 . The molars are relatively broad $\left(\mathrm{W}_{\mathrm{m}}=85.5-126.5 \mathrm{~mm}\right.$, mean $\left.=105 \mathrm{~mm}\right)$ and low $\left(\mathrm{H}_{\mathrm{m}}=100-142 \mathrm{~mm}\right.$, mean $\left.=122.5 \mathrm{~mm}\right)$. The relative crown height $\left(\mathrm{H}_{\mathrm{m}} / \mathrm{W}_{\mathrm{m}}\right)$ is between 1 and 1.6 (mean $=1.25)$. The molar plates are thick $\left(\mathrm{L}_{\mathrm{p}}=15-28.5 \mathrm{~mm}\right)$ and widely spaced. The lamellar frequency (LF) is between 3.5 and 6.5. The enamel is thick (ET $=2.5-4.2 \mathrm{~mm}$ ) and only weakly folded, if at all. 
Mammuthus trogontherii is based on material from Süssenborn (Germany), a site dated to the early Middle Pleistocene (c. $600 \mathrm{ka}$ ). The type material includes hundreds of isolated molars, several mandibles, isolated tusks and few postcranials (Palombo and Ferretti 2005).

Lister (1996) gave a detailed description of the nomenclature of Mammuthus trogontherii. The species "Elephas" trogontherii was founded by Pohlig (1885) for fossils from Süssenborn. Falconer (1857) had described the species "Elephas" armeniacus on the basis of a molar tooth from the region of Erzurum, Turkey. On the basis of priority, Aguirre (1969) and Maglio (1973) regarded armeniacus as a senior synonym of trogontherii. Although armeniacus cannot be regarded as a nomen oblitum, trogontherii is much more widely dispersed in the literature, and for this reason, Beden and Guérin (1975) have recommended its retention.

The description given below is mostly based on the work of Maglio (1973) and concerns the third upper molars (M3).

Plate formula: dp3: 7, Dp3: 5-6, dp4: 10, Dp4: 10-11, m1: 11-12, M1: 10-13, m2: 10-14, M2: 11-17, m3: 15-21, M3: 14-21.

The plate number $(\mathrm{P})$ on the third upper molar (M3) is between 14 and 21. The molars are narrow $\left(\mathrm{W}_{\mathrm{m}}=57-107.5 \mathrm{~mm}\right.$, mean $\left.=85 \mathrm{~mm}\right)$ and relatively high $\left(\mathrm{H}_{\mathrm{m}}=118-218 \mathrm{~mm}\right.$, mean $\left.=162.5 \mathrm{~mm}\right)$. The relative crown height $\left(\mathrm{H}_{\mathrm{m}} / \mathrm{W}_{\mathrm{m}}\right)$ is between 1.2 and $2.2($ mean $=1.65)$. The molar plates are thin $\left(\mathrm{L}_{\mathrm{p}}=12-20 \mathrm{~mm}\right)$ and closely spaced. The lamellar frequency (LF) is between 5 and 8 . The enamel is relatively thin $(\mathrm{ET}=1.8-2.5 \mathrm{~mm})$, weakly ribbed externally, and finely wrinkled.

\section{Question of validity of "Archidiskodon meridionalis ürömensis" Vörös 1979}

Nomenclatural comments on the taxon:

Prior to the taxonomic revision it is important to present some nomenclatural comments.

The valid generic name for the Late Pleistocene Eurasian mammoths is Mammuthus Brookes, 1828, with M. primigenius fixed as its type species. The name Archidiskodon Pohlig, 1888 (with Elephas meridionalis Nesti, 1825 fixed as its type species) is also taxonomically valid as a genus or subgenus, and its available for use by those who wish to differentiate meridionalis and other early species from Mammuthus. However, if one accepts the Archidiskodon meridionalis - Archidiskodon or Parelephas trogontherii - Mammuthus primigenius lineage in Eurasia and the Archidiskodon meridionalis - Mammuthus imperator - Mammuthus columbi linage in North America, then the Mammuthus genus could be interpreted as a polyphyletic group (Lister 1996). The problem is avoided by applying Mammuthus 
and the common name mammoth for all Eurasian Pliocene and Pleistocene representatives of this clade.

According to the ICZN rules* (Ride et al. 1999), the "ürömensis" is to be corrected to uromensis.

If one interprets this subspecies as a valid group, the proper use of this taxon is Mammuthus meridionalis uromensis on the basis of the aforementioned considerations.

\section{Dimensions:}

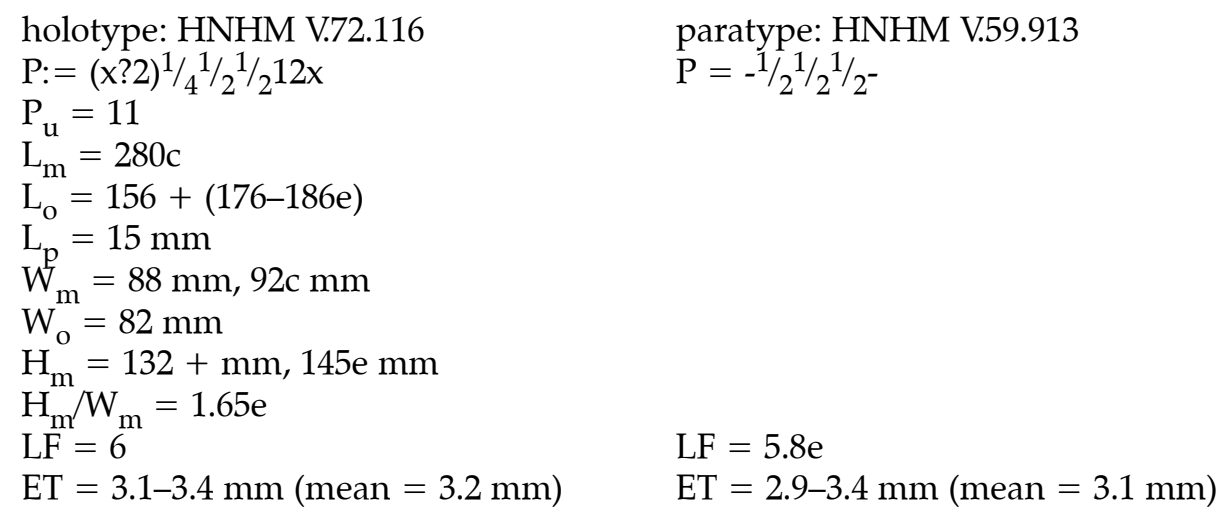

\section{Description:}

The type material of the Mammuthus meridionalis uromensis discussed in this article is stored in the Hungarian Natural History Museum (HNHM, Budapest, Hungary).

The paratype specimen (HNHM V.59.913, Fig. 2 on Pl. I) was found in Gombasek (Slovakia). It is a small fraction of a molar with 3 plates remaining. All of the remaining plates are broken in half. The enamel wear figures are annular to oval, which means that these are at a level between the top of the crown and the end of the clefts; therefore the only reliable measurement is the ET (2.9 to 3.4 $\mathrm{mm}$, mean $3.1 \mathrm{~mm}$ ). The paratype specimen can belong either to a M. meridionalis or a $M$. trogontherii on the basis of the measurable characters. It does not provide additional information about the subspecies, and is therefore not further discussed in this article.

\footnotetext{
*Article 32.5.2. A name published with a diacritic or other mark, ligature, apostrophe, or hyphen, or a species-group name published as separate words of which any is an abbreviation, is to be corrected. Article 32.5.2.1. In the case of a diacritic or other mark, the mark concerned is deleted, except that in a name published before 1985 and based upon a German word, the umlaut sign is deleted from a vowel and the letter "e" is to be inserted after that vowel (if there is any doubt that the name is based upon a German word, it is to be so treated).
} 
The holotype specimen (HNHM V.72.116, Fig. 1. on Pl. I) was found in the locality Üröm-hegy (in the Solymár Valley, at the northwestern boundary of Budapest, south of Üröm, Hungary). Jánossy (1986) referred to this specimen as "Archidiskodon trogontherii cromerensis". It is a fragment of the third upper left molar (M3 sin.) with 15 plates (the first three of which is broken) and a posterior platelet remaining, two plates and possibly an anterior talon are lacking at the front. Thus the most probable reconstruction of the plate number is $x 17 x$. The molar is somewhat broad $\left(\mathrm{W}_{\mathrm{m}}=88 \mathrm{~mm}\right.$ without the thin cement cover, which is 1.6 to $2.2 \mathrm{~mm}$ thick with an average of $2.0 \mathrm{~mm}$ on each side of the tooth) and slightly high $(\mathrm{H}=132+\mathrm{mm}, 145 \mathrm{e} \mathrm{mm})$. The relative crown height is $1.65 \mathrm{e}(1.58$ if the $W_{m}$ is measured with the cement cover). The molar plates are thin $\left(\mathrm{L}_{\mathrm{p}}=15\right.$ $\mathrm{mm})$ and closely spaced $(\mathrm{LF}=6)$. The enamel is relatively thick ( $\mathrm{ET}=3.1$ to 3.4 $\mathrm{mm}$, mean $3.2 \mathrm{~mm}$ ) and only weakly folded.

The previously described molar morphology (particularly the relatively high $\mathrm{P}$ and $\mathrm{H}_{\mathrm{m}} / \mathrm{W}_{\mathrm{m}}$ ) suggests that the holotype specimen belongs to Mammuthus trogontherii rather than a subspecies of $M$. meridionalis. The late populations of the "true" M. meridionalis never reached the 17 lamellae. The enamel is somewhat thicker than the typical M. trogontherii morphology; however, this mosaic characteristic of the specimen is not unprecedented in the European mammoth material, and it could support the scenario proposed by Lister and Sher (2001) and Lister et al. (2005) for the evolution of mammoths during the latest Early Pleistocene and the earliest Middle Pleistocene as discussed below.

\section{Additional material}

Another paratype specimen was designated by Vörös (1979). This specimen (SNM P.173) is a fragment of a third upper right molar from Zoltan (Romania) stored in the Székely National Museum (SNM, Sfântu Gheorghe, Romania). It was not involved in the revision.

Vörös (1980) presented 4 molars (in Table 1 of his article) from Visonta (Hungary), which were identified as "Parelephas trogontherii". Thereafter, with a further addition of a single molar, Fodor and Vörös (1988) re-identified these specimens as "Archidiskodon meridionalis ürömensis" without a detailed explanation. These specimens were not depicted; thus the identification of the aforementioned species on the basis of the published measurements only, is slightly confusing because there is a small shift in the data tables comparing the two articles. Nevertheless it seems that the material from Visonta belongs both to M. meridionalis (e.g. right $\mathrm{m} 3$ with $\mathrm{P}=12, \mathrm{H}_{\mathrm{m}} / \mathrm{W}_{\mathrm{m}}=1.0, \mathrm{LF}=5$ and $\mathrm{ET}=3.1 \mathrm{~mm}$ ) and $M$. trogontherii (e.g. left $\mathrm{m} 3$ with $\mathrm{P}=18, \mathrm{H}_{\mathrm{m}} / \mathrm{W}_{\mathrm{m}}=1.1$ ?, $\mathrm{LF}=5$ and $\mathrm{ET}=3.0$ $\mathrm{mm})$.

Vörös $(1983,2004)$, in addition to the aforementioned sites, reported "Archidiskodon meridionalis ürömensis" material from Úri str. 72 (Vár-hegy, Budapest, Hungary), Csúcsoshegy (Szomód, Hungary), the terrace of the Sajó River 
Plate I

1. HNHM V.72.116. Mammuthus trogontherii third upper left molar (M3) from Üröm-hegy (Hungary) from lingual (A) and from occlusal (B) view. C: Posterior view of a plate (VIth or possibly the 12th) in midcrown area.

2. HNHM V.59.913. Mammuthus sp. molar fragment from Gombasek (Slovakia) from occlusal view (A) and the lateral view of the saggital fracture (B)
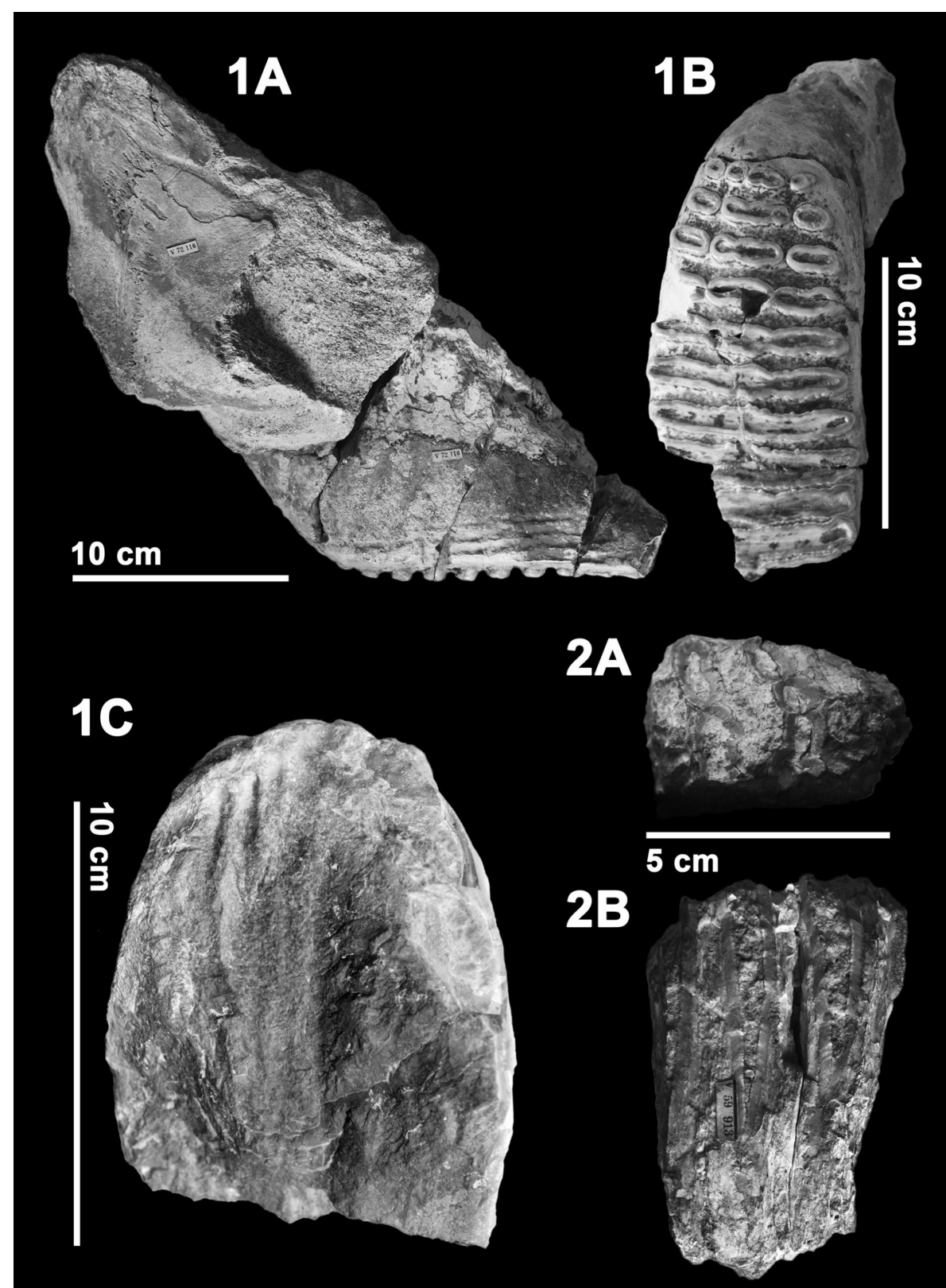

Central European Geology 52, 2009 
(Miskolc, Hungary), and locality 3 in Villány (Hungary). Measurement data were not published and only one tooth was depicted (HNHM V.82.49., right $\mathrm{m} 3$ from Csúcsoshegy, Fig. 4/1. in Vörös 2004). The HNHM V.82.49. specimen most likely belongs to $M$. meridionalis on the basis of the measurable characters $\left(\mathrm{P}=\mathrm{x} 14 \mathrm{x}, \mathrm{P}_{\mathrm{u}}\right.$ $=6, \mathrm{~L}_{\mathrm{m}}=276 \mathrm{~mm}, \mathrm{~L}_{\mathrm{o}}=99 \mathrm{~mm}, \mathrm{~L}_{\mathrm{p}}=20 \mathrm{~mm}, \mathrm{~W}_{\mathrm{m}}=97 \mathrm{~mm}, \mathrm{~W}_{\mathrm{o}}=88 \mathrm{~mm}, \mathrm{H}_{\mathrm{m}}^{\mathrm{u}}$ $=130 \mathrm{~mm}, \mathrm{H}_{\mathrm{m}} / \mathrm{W}_{\mathrm{m}}=1.34, \mathrm{LF}=4.8, \mathrm{ET}=3.3 \mathrm{~mm}$ ).

\section{Stratigraphic interpretation}

The type locality of the Mammuthus meridionalis uromensis is Üröm-hegy. The fauna-bearing calcareous mud layer is situated in the northeastern quarry, which was established in a large freshwater limestone table. The limestone was deposited on the eroded surface of the Middle Oligocene Kiscell Clay. The main mammalian assemblage was collected by Endre Krolopp. Jánossy (1986) correlated the mammalian assemblage with the Templomhegyian substage of the local biochronological system on the basis of the mammalian fauna, particularly on the basis of the co-occurrence of the ancient water mole Mimomys savini and "Archidiskodon trogontherii cromerensis". Furthermore this locality provided the earliest occurrence of Hippopotamus in Hungary (Jánossy 1986).

The Templomhegyian substage is characterized by the co-occurrence of Mimomys savini, Prolagurus pannonicus as well as Microtus subgenera more evolved than Allophaiomys; thus it can be correlated with the Mimomys savini Rodent Zone (from c. 0.9 Ma to c. 0.6 Ma in Central Europe according to Maul and Markova 2007, as well as Sala and Masini 2007) in the Late Biharian Small Mammal Age (Fig. 2).

According to Maul and Markova (2007) the exact age of the locality can be refined with two characteristic horizons: 1. Mimomys pusillus is unknown from Mimomys savini faunas of the "Cromerian Interglacial II." since it probably disappeared before this event. 2. The Mimomys savini - Arvicola transition in Central Europe occurred after "Cromerian Interglacial II." (therefore probably in MIS 16). On the basis of the absence of Mimomys pusillus and Arvicola a date in the region of MIS 19-17 seems likely (i.e. c. 0.8 Ma-c. 0.7 Ma) (Fig. 2).

\section{Discussion}

In order to place the Mammuthus trogontherii molar (HNHM V.72.116) from the locality Üröm-hegy in space and time, it is necessary to discuss the elementary steps of the M. meridionalis-M. trogontherii transition in Europe (and in Asia). Mammoth evolution in Eurasia represents one of the best-studied examples of evolutionary pattern and processes in the terrestrial fossil record. Many publications deal with this issue. In the following the most important results of Lister (1996), Lister and Sher (2001), Wei et al. (2003) Lister et al. (2005) and Palombo and Ferretti (2005) related to this topic will be discussed. 


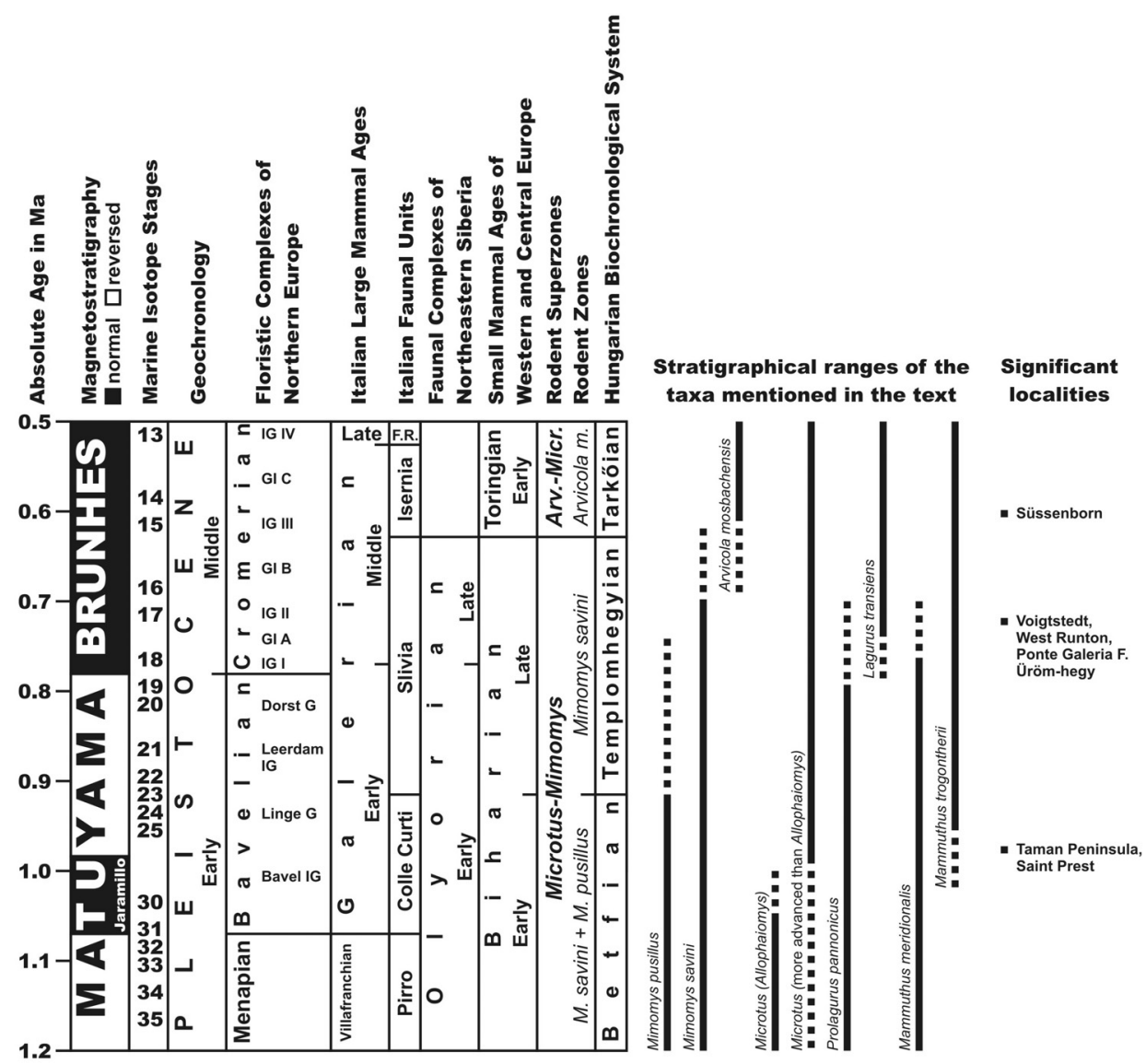

Fig. 2

Integrated stratigraphic scheme for the different chronologies discussed in the text (modified from Breda and Marchetti 2005; Lister et al. 2005; Palombo and Ferretti 2005; Masini and Sala 2007; Maul and Markova 2007; Sala and Masini 2007). The Early-Middle Pleistocene boundary was adjusted to the proposal of Richmond (1996). Abbreviations: F.R.: Fontana Ranuccio, Arv.-Micr.: Arvicola-Microtus, Arvicola m.: Arvicola mosbachensis

Elephantids referred to as Mammuthus had entered Europe, apparently from Africa, not later than 3 Ma. The earliest stage, M. rumanus, spread across Europe and eastwards to China. In the interval 2.6-2.0 Ma, this taxon was replaced by mammoths which were dentally more advanced (M. meridionalis), but the details of this transition, including the question of where and how it occurred, are unknown (Lister et al. 2005). Typical M. meridionalis morphology in Europe $(\mathrm{P}=$ 12 to 14 with outliers at 11 and 15 , mean $\mathrm{H}_{\mathrm{m}} / \mathrm{W}_{\mathrm{m}}=1.2$ ) is achieved by c. 2.4 to 2.2 Ma (Khapry, Russia) (Lister and Sher 2001).

Wei et al. (2003) reported some morphologically advanced remains referable to $M$. trogontherii in China. The molars have advanced tooth morphology with $\mathrm{P}=$ 
17-18 on M3, relatively higher and narrower crown, larger LF and thinner enamel compared with all the contemporaneous mammoths. The mammothbearing horizon was dated to c. 2.0-1.8 Ma on the basis of rodent biostratigraphy. The upper limit of the emergence of the mammoth-bearing strata was dated by paleomagnetism to c. $1.36 \mathrm{Ma}$.

Lister and Sher (2001) examined mammoth material from northeastern Siberia (between the Lena and Kolyma River valleys) from the Early Olyorian dated by paleomagnetism and microfauna to the interval of c. 1.2-0.8 Ma (Fig. 2). The molars have similar tooth morphology to typical European M. trogontherii from Süssenborn.

The earliest detected M. trogontherii morphology in Europe is at the easternmost part of the continent (Taman Peninsula, Russia) whereas contemporaneous samples in Western Europe (e.g. Saint-Prest, France) showed slight advancement in $\mathrm{P}$ to a range of 13 to 15 but altogether remained at primitive M. meridionalis level (Lister and Sher 2001). The Early Olyorian sample is approximately equivalent to the European Taman sample in age (c. 1.0 Ma) but is more derived in molar morphology.

These observations led to the suggestion that the M. trogontherii morphology had arisen allopatrically from an indigenous population of $M$. meridionalis in eastern Asia, probably in China (in the interval c. 2.0-1.5 Ma), and spread to Siberia by c. 1.2 Ma, where it underwent further evolution to more advanced $M$. trogontherii (Lister et al. 2005). The earlier initiation and persistent advancement of grazing adaptations in eastern Asian mammoths, compared to those in Europe, was most likely linked to the earlier advent and greater severity and continuity of the periglacial conditions in that region. The continental climate of China in the Early Pleistocene, and the existence of steppic as well as forest vegetation, provide a selective force for the origin of M. trogontherii (Lister and Sher 2001; Lister et al. 2005).

In keeping with the observed zoogeographic pattern the aforementioned hypothesis suggests that the morphology of European M. trogontherii, starting from c. 1.0 Ma could be derived from immigrants either from Siberia or from China, or that the latter two regions might have formed an essentially continuous distribution which contributed to European populations. However, as pointed out by Lister and Sher (2001) and Lister et al. (2005), the complexity of European forms in the transitional period (as discussed below) does not support a "clean" allopatric replacement whereby the European ancestor (typical M. meridionalis) was simply displaced by an incoming daughter species (typical $M$. trogontherii).

The observed morphologic and zoogeographic pattern is somewhat complicated in Europe in the interval 1.0-0.7 Ma. The material from the Taman Peninsula shows enhanced variability in the direction of $M$. trogontherii and has been posited as a key "intermediate" between the two species. Although this sample as a whole is intermediate in both $\mathrm{P}$ and $\mathrm{Hm} / \mathrm{Wm}$ between the typical $M$. meridionalis and $M$. trogontherii, it has a rather broad morphological range $(\mathrm{P}=14$ 
to $19, \mathrm{H}_{\mathrm{m}} / \mathrm{W}_{\mathrm{m}}=1.6$ to 1.9 ), and the distribution of these characters is bimodal (Lister and Sher 2001). Two smaller samples from Voigtstedt (Germany) and West Runton (England) At around 0.8-0.7 Ma include molars at full $M$. trogontherii level ( $\mathrm{P}=19$ to $22, \mathrm{H}_{\mathrm{m}} / \mathrm{W}_{\mathrm{m}}=1.6$ to 1.9$)$, but also specimens showing "advanced" $M$. meridionalis morphology in one or more characters. Some specimens have "mosaic" morphology (for example, trogontherii-like hypsodonty index but meridionalis-like plate number, or vice versa), whereas others show "intermediate" values $\left(\mathrm{P}=16, \mathrm{H}_{\mathrm{m}} / \mathrm{W}_{\mathrm{m}}=1.5\right)$ between typical $M$. trogontherii and $M$. meridionalis level (Lister and Sher 2001).

The material from Üröm-hegy (dated to c. $0.8-0.7 \mathrm{Ma}$ on the basis of rodent biostratigraphy) should be inserted at this point on the basis of geologic age as well as molar morphology. The latest Mimomys savini in Central Europe are known from faunas of Brunhes paleomagnetic chron (e.g. West Runton and Voigtstedt), referred to "Cromerian Interglacial II." (Maul and Markova 2007). These localities are essentially time equivalent with the Üröm-hegy locality (Fig. 2). Not only the geologic age but the observed mosaic molar morphology (meridionalis-like ET, intermediate or slightly advanced $\mathrm{H}_{\mathrm{m}} / \mathrm{W}_{\mathrm{m}}$ and LF, trogontherii-like P) of the NHNM V.72.116 specimen is also very similar to several representatives of the material from Voigtstedt, as Vörös (1979) noticed.

Palombo and Ferretti (2005) indicated the co-occurrence of the M. meridionalis and M. trogontherii in the Ponte Galeria Formation (Italy, Slivia Faunal Unit). The Slivia Faunal Unit correlates directly with the Late Biharian (Fig. 2) based on the occurrence of Microtus subgenera more evolved than Allophaiomys associated with Mimomys savini.

The co-occurrence of M. meridionalis and $M$. trogontherii in several European localities in the interval between 1.0 and $0.7 \mathrm{Ma}$, with mosaic and intermediate specimens among the samples, suggests an evolutionary explanation. As discussed by Lister and Sher (2001) and Lister et al. (2005), it is likely that the entire Eurasian M. meridionalis-M. trogontherii complex had a "metapopulation" structure (a series of populations with greater or lesser degrees of connection between them), and that the transition between the two species in Europe was achieved by input from the East, either in the form of migrating herds, and/or by gene flow without the long distance movement of individual animals. As pointed out by Lister (1996) and van Essen (2003) populations of M. meridionalis and M. trogontherii morphology might, for example, have occupied different areas of the European continent (meridionalis occurred in more temperate conditions, trogontherii in cooler), perhaps shifting their distributions seasonally or with short-term climatic cycles. The genetic mixing between the adjacent populations resulted in a hybrid zone, which is responsible for mosaic or intermediate individuals as well as for those which correspond to the parent populations in all characters. There must also have been selection in Europe, on an individual and/or population level, which resulted in the dominance of the incoming 
morphology. By c. $0.6 \mathrm{Ma}$, only M. trogontherii occurred in Europe, as at Süssenborn, the type locality of the species (Lister and Sher 2001).

\section{Conclusions}

A single tooth from Üröm-hegy (HNHM V.72.116) referred to as "Archidiskodon trogontherii cromerensis" by Jánossy (1986) was designated as the holotype specimen of "Archidiskodon meridionalis ürömensis" by Vörös (1979). In the light of recent studies it appears that this molar is not only a misinterpreted specimen, which can be referred to $M$. trogontherii, such as several other representatives of the type material of European meridionalis subspecies, but a representative of a very important period of mammoth evolution in Eurasia.

The latest Early Pleistocene and the earliest Middle Pleistocene represents a crucial time in elephant diversity and turnover in Europe, with the possible occurrence of three taxa (Elephas antiquus, Mammuthus meridionalis and Mammuthus trogontherii). Evidence suggests that the series of European mammoth populations ("transitional" between typical M. meridionalis and M. trogontherii) from this period do not follow each other in an orderly chronological succession but overlap in time.

The creation of more and more meridionalis and trogontherii subspecies do not bring us any closer to understanding such a complex zoogeographic and evolutionary pattern. The only way to get a clearer picture is to improve sample sizes and to fill gaps in stratigraphy and in taxonomic and geographical sampling with additional material. As noted by Todd and Roth (1996) a call for more material is hardly a novel conclusion, but only through further development of these kind of data can we begin to understand the morphological transformations of Pliocene-Pleistocene elephants.

\section{Acknowledgements}

I am grateful to Mihály Gasparik (Hungarian Natural History Museum, Department of Geology and Paleontology) for our fruitful discussions and for granting me access to the type material. I would sincerely like to thank István Vörös (Hungarian National Museum, Department of Archaeology) who kindly gave me some of his papers. Hans van Essen (Leiden University, Faculty of Archaeology) is especially thanked for invaluable advice as well as for critically reading the manuscript. I am indebted to the staff of the Department of Paleontology (Ë̈tvös Loránd University) for their encouragement. 


\section{References}

Aguirre, E. 1969: Evolutionary history of the elephant. - Science, 164, pp. 1366-1376.

Beden, M. 1979: Les élephants (Loxodonta et Elephas) d'Afrique Orientale: systématique, phylogénie, intérêt biochronologique. - Doctoral dissertation, Université de Poitiers, Poitiers, 567 p.

Beden, M., C. Guérin 1975: Les Proboscidiens (Mammalia) du gisement pléistocène moyen des Abîmes de La Fage à Noailles (Corrèze). - Nouvelles Archives du Muséum d'Histoire naturelle de la Ville de Lyon, 13, pp. 69-87.

Bergh, G.D. van den 1999: The Late Neogene elephantoid-bearing faunas of Indonesia and their palaeozoogeographic implications. A study of the terrestrial faunal succession of Sulawesi, Flores and Java, including evidence for early hominid dispersal east of Wallace's Line. - Scripta Geologica, 117, pp. 1-419.

Breda, M., M. Marchetti 2005: Systematical and biochronological review of Plio-Pleistocene Alceini (Cervidae; Mammalia) from Eurasia. - Quaternary Science Reviews, 24, pp. 775-805.

Brookes, J. 1828: A Catalogue of the Anatomical and Zoological Museum of Joshua Brookes. - Esq. George Robins, London, $76 \mathrm{p}$

Coppens, Y., M. Beden 1980: Mammuthus meridionalis depereti n. subsp. (Mammalia, Elephantidae), noveau mammouth du Pléistocène inférieur d'Europe occidentale. - Comptes Rendus de l'Académie des Sciences, Series II, 294, pp. 291-294.

Depéret, C., L. Mayet 1923: Monographie des éléphants Pliocènes de l'Europe et de l'Afrique du Nord. - Annales de l'Université de Lyon, nouvelle série, Sciences Médecine, 42, pp. 91-221.

Dietrich, W.O. 1965: Fossile Elephantzähne von Voigtstedt in Thüringen. - Paläontologische Abhandlungen, Abteilung A (Paläozoologie), 2, pp. 521-536.

Dubrovo, I.A. 1964: Elephants of the genus Archidiskodon in the USSR territory. Paleontologicheskiy Zhurnal, 3, pp. 82-94. (in Russian)

Essen, H. van 2003: Tooth morphology of Mammuthus meridionalis from the southern bight of the North Sea and from several localities in the Netherlands. - Deinsea, 9, pp. 453-511.

Falconer, H. 1857: On the species of mastodon and elephant occurring in the fossil state in Great Britain. Part I. - Quarterly Journal of the Geological Society of London, 13, pp. 307-360.

Fodor, L., I. Vörös 1988: Diluviale Ursäugetier-Reste aus Visonta. - Agria, 24, pp. 5-20. (In Hungarian with German abstract.)

Foronova, I.V. 2007: Thin-enamel specialization in mammoth evolution: An example of direction selection. - Quaternary International, 169-170, pp. 95-104.

Gray, J.E. 1821: On the Natural Arrangement of Vertebrate Animals. - London Medical Repository, 15, pp. 296-310.

Illiger, C. 1811: Prodromus systematis mammalium et avium additis terminis zoographicis utriusque classis. - C. Salfeld, Berlin, 301 p.

Jánossy, D. 1986: Pleistocene Vertebrate Faunas of Hungary. - Developments in Palaeontology and Stratigraphy, 8, pp. 1-208.

Linnaeus, C. 1758: Systema naturae per regna tria naturae, secundum classes, ordines, genera, species cum characteribus; synonymis, locis. - Laurentii salvii, Stockholm, $824 \mathrm{p}$.

Lister, A.M 1996: Evolution and taxonomy of Eurasian mammoths. - In: ShoshanyJ., P. Tassy (Eds): The Proboscidea: evolution and palaeoecology of elephants and their relatives. - Oxford University Press, Oxford, pp. 203-213.

Lister, A.M, A.V. Sher 2001: The origin and evolution of woolly mammoth. - Science, 294, pp. 1094-1097.

Lister, A.M, A.V. Sher, H. van Essen, G. Wei 2005: The pattern and process of mammoth evolution in Eurasia. - Quaternary International, 126-128, pp. 49-64.

Maglio, V.J. 1973: Origin and evolution of the Elephantidae. - Transactions of the American Philosophical Society, New Series, 63/3, pp. 1-149. 
Masini, F, B. Sala 2007: Large- and small-mammal distribution patterns and chronostratigraphic boundaries from the Late Pliocene to the Middle Pleistocene of the Italian peninsula. Quaternary International, 160, pp. 43-56.

Maul, L.C., A.K. Markova 2007: Similarity and regional differences in Quaternary arvicolid evolution in Central and Eastern Europe. - Quaternary International, 160, pp. 81-99.

Nesti, F. 1825: Sulla nuova specie di elefante fossile del Valdarno all'Illustrissimo Sig. Dott. Prof. Ottaviano Targioni Tozzetti (Lettere sopra alcune ossa fossili del Valdarno non per anco descritte). - Nuovo Giornale di Lettere, 11/24, pp. 195-216.

Palombo, M.R., M.P. Ferretti 2005: Elephant fossil record from Italy: knowledge, problems, and perspectives. - Quaternary International, 126-128, pp. 107-136.

Pohlig, H. 1885: Über eine Hipparionen-Fauna von Maragha in nord-Persien, über fossile Elephanten Reste Caucasien und Persien und über die resultate einer Monographie der fossilen Elephanten Deutschlands und Italiens. - Zeitschrift der Deutschen Geologischen Gesellschaft, 37, pp. 1022-1027.

Pohlig, H. 1888: Dentition und Kranologie des Elephas antiquus Falc. mit Beiträgen über Elephas primigenius Blum. und Elephas meridionalis Nesti. - Nova Acta Academiae Caesarae LeopoldinoCarolinae Germanicae Naturae Curiosorum, 53, pp. 1-282.

Richmond, G.M. 1996: The INQUA approved provisional Lower-Middle Pleistocene boundary. - In: Turner, C. (Ed.): The Early Middle Pleistocene in Europe. - Balkema, Rotterdam, pp. 226-319.

Ride, W.D.L., H.G. Cogger, C. Dupuis, O. Kraus, A. Minelli, F.C. Thompson, P.K. Tubbs (Eds:) 1999: International Code of Zoological Nomenclature. - International Trust for Zoological Nomenclature, London, $306 \mathrm{p}$.

Sala, B., F. Masini 2007: Late Pliocene and Pleistocene small mammal chronology in the Italian peninsula. - Quaternary International, 160, pp. 4-16.

Todd, N.E., V.L. Roth 1996: Origin and radiation of the Elephantidae. - In: Shoshany, J., P. Tassy (Eds): The Proboscidea: evolution and palaeoecology of elephants and their relatives. - Oxford University Press, Oxford, pp. 193-202.

Vörös, I. 1979: Archidiskodon meridionalis ürömensis n. ssp. from the lower Pleistocene of the Carpathian Basin. - Fragmenta Mineralogica et Palaeontologica, 9, pp. 5-8.

Vörös, I. 1980: Fossil Elephantidae of Hungary. Part I. The Elephantidae finds of North Hungary. Folia Historico-Naturalia Musei Matraensis, 6, pp. 13-49. (In Hungarian with English and German abstracts.)

Vörös, I. 1983: Elephantiden-Reste aus dem Karpathenbecken. - Fragmenta Mineralogica et Palaeontologica, 11, pp. 61-84.

Vörös, I. 2004: Biochronology of fossil Elephantidae in Hungary. - Folia Archaeologica, 51, pp. 9-28.

Wei, G., H. Taruno, C. Jin, F. Xie 2003: The earliest specimens of the steppe mammoth, Mammuthus trogontherii, from the Early Pleistocene Nihewan Formation, North China. - Earth Science, 57, pp. 269-278. 